\title{
A Novel Water-Soluble Photosensitizer for Photodynamic Inactivation of Gram-Positive Bacteria
}

\author{
Zihuayuan Yang ${ }^{1}$, Ying Qiao ${ }^{1}$, Junying $\mathrm{Li}^{1}$, Fu-Gen $\mathrm{Wu}^{1}$, and Fengming Lin $^{1}$ \\ ${ }^{1}$ Southeast University
}

April 28, 2020

\begin{abstract}
Antimicrobial photodynamic therapy (APDT) is a promising alternative to traditional antibiotics for bacterial infections, which inactivates a broad spectrum of bacteria. However, it has some disadvantages including poor water solubility and easy aggregation of hydrophobic photosensitizers (PS), and poor tissue penetration and cytotoxicity when using UV as light source, leading to photodynamic therapy efficacy. Herein, we develop a novel water-soluble natural PS (sorbicillinoids) obtained by microbial fermentation using filamentous fungus Trichoderma reesei (T. reesei). Sorbicillinoids could effectively generate singlet oxygen (1O2) under UV light irradiation, and ultimately display photoinactivation activity on Gram-positive bacteria, but not Gram-negative ones. Staphylococcus aureus (S. aureus) treated with sorbicillinoids and UV light displayed high levels of intracellular reactive oxygen species (ROS), notable DNA photocleavage, and compromised membrane permeability without overt cell membrane disruption. Moreover, the dark toxicity, phototoxicity or hemolysis activity of sorbicillinoids is negligible, showing its excellent biocompatibility.
\end{abstract}

\section{INTRODUCTION}

Diseases caused by bacterial infections, such as pneumonia and sepsis, threaten the lives of millions of people every year (Jones et al., 2008; Theuretzbacher, 2013). The most widely used strategy for coping with bacterial infections at present is antibiotics (Fischbach and Walsh, 2009). However, the abuse of antibiotics in recent decades has led to an increase in the resistance of bacteria (Taubes, 2018), which causes the emergence of multi-drug resistant (MDR) bacteria (Levy and Marshall, 2004; Tenover, 2006). Thus, it is urgent to develop new antibiotics and efficient antibacterial therapies to fight MDR bacteria. Many novel antibiotics have been explored to successfully combat MDR bacterial infection, including carbon dots nanoparticles (NP) (Yang et al., 2016; Ran et al., 2019) and cationic antibacterial peptides (Liu et al., 2009; Lam et al., 2016). In addition, new efficient antibacterial therapies have been also applied in treating bacterial infections, such as photodynamic therapy (PDT) (Hamblin and Hasan, 2004; Liu et al., 2015) and photothermal therapy (PTT) (Zhao et al., 2018; Wu et al., 2019). Antimicrobial photodynamic therapy (APDT) has been widely reported as a promising alternative to traditional antibiotics in the past few years (Jia et al., 2017; Ravikumar et al., 2018). APDT generally involves molecular oxygen, light source, and photosensitizer (PS). With light irradiation of a suitable wavelength, PS converts molecular oxygen into reactive oxygen species (ROS) (Liu et al., 2015), primarily singlet oxygen $\left({ }^{1} \mathrm{O}_{2}\right)$. The highly active ROS can cause damage to important biomolecules such as lipids (Zhang et al., 2019), proteins (Davies, 2003), and DNA (Alves et al., 2013), ultimately leading to bacterial cell death. Unlike conventional antibiotics, APDT only irradiates the lesion location and does not cause damage to other parts (Hamblin and Hasan, 2004), thereby achieving selective bacterium-killing. More importantly, APDT can inactivate a broad spectrum of bacteria, opening new avenues for the development of new antibacterial therapies (Liu et al., 2015).

Most currently available PSs for APDT have poor solubility in water, showing a strong tendency to aggregate, ultimately leading to poor photodynamic therapy efficacy (Almeida-Marrero et al., 2018). To improve their 
hydrophilicity, a variety of modification methods were applied by physical encapsulation or chemical covalent conjugation of PSs to nanocarriers such as peptide nanoparticles (Han et al., 2015), polymer nanoparticles (Parthasarathy et al., 2015), and liposomes (Malcher et al., 2008). However, these surface modification methods are time-consuming and usually bring some unexpected consequences such as low biocompatibility, which may compromise the clinical application of APDT. Another issue that plagues APDT was the need of UV light for some PSs like metal oxide NPs zinc oxide (ZnO) NPs and titanium dioxide $\left(\mathrm{TiO}_{2}\right) \mathrm{NPs}(\mathrm{Huh}$ and Kwon, 2011), for the reason that UV light is cytotoxic to human cells and has poor tissue penetration (Wegener eet al., 2017). Therefore, it is urgent to find new PSs for the APDT system to overcome these issues. Natural products from fungus and plants have been reported as a promising alternative to conventional PSs such as hypericin (García et al., 2015), curcumin (Tonon et al., 2015), hypocrellin (Zhenjun and Lown, 1990) and cationic riboflavin (Maisch et al., 2014). The compounds are usually derived from secondary metabolism. Natural products as PSs have the advantages of good biocompatibility, wide source, and high ${ }^{1} \mathrm{O}_{2}$ yield (Abrahamse and Hamblin, 2016).

Sorbicillinoids are hexaketide metabolites isolated from both marine and terrestrial ascomycetes, such as Trichoderma, Acremonium ,Aspergillus , Emericella , Penicillium ,Phaeoacremonium, and Scytalidium (Meng et al., 2016). Most of these compounds have characteristic structures, including bicyclic or tricyclic structures and C1'-C6' sorbyl sidechain. Sorbicillinoids were divided into four classes based on their structure (Harned and Volp, 2011): monomeric sorbicillinoids, bisorbicillinoids, trisorbicillinoids, and hybrid sorbicillinoids. In recent years, various potential applications of sorbicillinoids have been exploited, such as antioxidants (Abe and Hirota, 2002; Kawahara et al., 2012), antibiotics (Guo et al., 2015; Meng et al., 2018), and anticancer drugs (Lai et al., 2019; Meng et al., 2019). However, research on sorbicillinoids as a PS for the APDT system has not been reported.

In this study, we discovered a new type of natural material as a water-soluble PS for APDT (Scheme 1). Sorbicillinoids produced by Trichoderma reesei converts oxygen molecules into ${ }^{1} \mathrm{O}_{2}$ effectively under mild ultraviolet (UV) irradiation. As a result, sorbicillinoids exhibited great APDT effect toward Gram-positive bacteria. The underlying mechanism of the light-activated antibacterial activity of sorbicillinoids was explored by monitoring intracellular ROS, DNA photocleavage and cell membrane damage. Furthermore, the biocompatibility of sorbicillinoids-mediated APDT was evaluated using MTT assay and hemolysis assay.

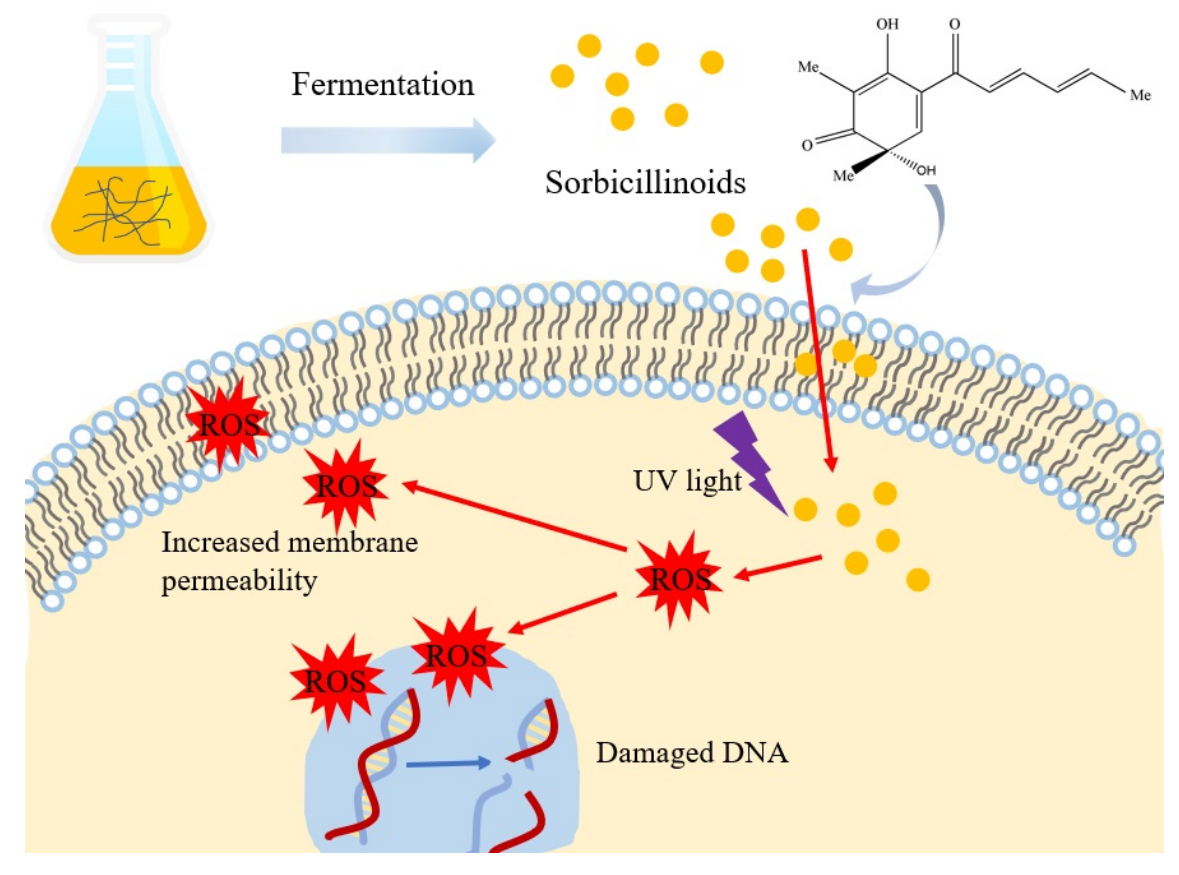


Scheme 1. Schematic Illustration of Photodynamic Inactivation against S. aureus by Sorbicillinoids under UV Light Irradiation.

\section{MATERIALS AND METHODS}

\subsection{Materials}

Luria Bertani (LB) broth, LB agar and potato dextrose agar (PDA) were purchased from Beijing Land Bridge. Singlet oxygen sensor green (SOSG) kit was acquired from Molecular Probes Inc. (Eugene, Oregon, USA). Propidium iodide (PI) was obtained from KeyGen Biotech (Nanjing, China). Glutaraldehyde, 3-(4,5dimethyl-2-thiazolyl)-2,5-diphenyl-2- $H$-tetrazolium bromide (MTT), methanol, ethanol, dimethyl sulfoxide (DMSO), and triton X-100 were purchased from Aladdin Chemistry Co., Ltd. (Shanghai, China). Reactive oxygen species assay kit was bought from Beyotime Biotech Inc. (Shanghai, China). All other chemicals used in this study were purchased from Sigma-Aldrich (St. Louis, MO, USA). All solutions were prepared with deionized water $(18.2 \mathrm{M} \Omega \mathrm{cm}$ ) purified by a Milli-Q water purification system (Milli-Q, Millipore, USA).

\subsection{Sorbicillinoids production}

The conidia produced by Trichoderma reesei strain ZC121 grown on PDA plates for 7 days at $28^{\circ} \mathrm{C}$, were inoculated into $10 \mathrm{~mL}$ sabouraud dextrose broth (SDB) and incubated for $48 \mathrm{~h}$ with $200 \mathrm{rpm}$ at $28{ }^{\circ} \mathrm{C}$. Pre-grown mycelia were inoculated with an inoculation ratio of $10 \%(\mathrm{v} / \mathrm{v})$ into $50 \mathrm{~mL}$ Trichoderma minimal media (Minty et al., 2013) (TMM) with $2 \%$ glucose, and then incubated for $120 \mathrm{~h}$ with $200 \mathrm{rpm}$ at $28{ }^{\circ} \mathrm{C}$. The suspension was centrifuged at $14000 \mathrm{rpm}$ for $15 \mathrm{~min}$ at $4{ }^{\circ} \mathrm{C}$ to remove Trichoderma reesei cells and other solid materials, and the supernatant was dried at $120{ }^{\circ} \mathrm{C}$ in an oven. The obtained powder was dissolved in methanol to remove inorganic salt. Methanol was evaporated at $60{ }^{\circ} \mathrm{C}$ under a nitrogen atmosphere to obtain sorbicillinoids. TMM medium was composed of the following chemicals (all concentration unit is $\mathrm{g} / \mathrm{L}$ unless otherwise noted): $\left(\mathrm{NH}_{4}\right)_{2} \mathrm{SO}_{4}, 4.0 ; \mathrm{KH}_{2} \mathrm{PO}_{4}, 6.5$; Tween-80, $0.0186 \%$ (v/v); Yeast extract, 0.75; Tryptone, 0.25; Maleic acid, 11.6; $\mathrm{FeSO}_{4} \cdot 7 \mathrm{H}_{2} \mathrm{O}, 0.005 ; \mathrm{MnSO}_{4} \cdot \mathrm{H}_{2} \mathrm{O}, 0.0016 ; \mathrm{ZnSO}_{4} \cdot 7 \mathrm{H}_{2} \mathrm{O}, 0.0014 ; \mathrm{CoCl}_{2} \cdot 6 \mathrm{H}_{2} \mathrm{O}, 0.002$; $\mathrm{MgSO}_{4}, 0.60 ; \mathrm{CaCl}_{2}, 0.60$; urea, 1.0. Then the $\mathrm{pH}$ of TMM was adjusted to 5.8 by $\mathrm{NaOH}$.

\subsection{Singlet oxygen generation assay}

The generation of ${ }^{1} \mathrm{O}_{2}$ was measured with singlet oxygen sensor green (SOSG). $1 \mu \mathrm{L}$ SOSG dissolved in methanol was mixed with $2 \mathrm{~mL} 0.9 \% \mathrm{NaCl}$ and $50 \mu \mathrm{g} / \mathrm{mL}$ sorbicillinoids in $0.9 \% \mathrm{NaCl}$, followed by UV light $(2$ $\left.\mathrm{mW} / \mathrm{cm}^{2}\right)$ or white light irradiation $\left(8 \mathrm{~mW} / \mathrm{cm}^{2}\right) .0 .9 \% \mathrm{NaCl}$ without any light irradiation was set as control. Then, the fluorescence intensity of the samples at $528 \mathrm{~nm}$ was measured by a spectrofluorophotometer (RF5301PC, Shimadzu, Japan).

\subsection{Antibacterial activity assay}

Escherichia coli (E . coli), andStaphylococcus aureus ( . aureus ) were selected to present Gram-negative and Gram-positive bacteria, respectively. $E$. coli or $S$. aureus were cultivated overnight in LB medium at 37 ${ }^{\circ} \mathrm{C}$ with $200 \mathrm{rpm}$. Bacteria were obtained from bacteria suspension overnight by centrifugation at $8000 \mathrm{rpm}$ for $5 \mathrm{~min}$ and then resuspended in $0.9 \% \mathrm{NaCl}$. The optical density of the resuspension at $600 \mathrm{~nm}\left(\mathrm{OD}_{600}\right)$ was measured using a UV-vis spectrophotometer (UV-2600, Shimadzu, Japan). Then, the resuspension was diluted to $\mathrm{OD}_{600}=0.5$ with $0.9 \% \mathrm{NaCl}$. After the dilution, $100 \mu \mathrm{L}$ bacteria suspension was mixed with $900 \mu \mathrm{L}$ sorbicillinoids dissolved in $0.9 \% \mathrm{NaCl}$ at different concentrations. The final concentrations of sorbicillinoids were $0,50,100,200,250$, and $300 \mu \mathrm{g} / \mathrm{mL}$. for $S$.aureus $(0,200,400,600,800$, and $1000 \mu \mathrm{g} / \mathrm{mL}$. for $E$.coli ). After irradiation under UV light $\left(2 \mathrm{~mW} / \mathrm{cm}^{2}\right)$ for $30 \mathrm{~min}, 100 \mu \mathrm{L}$ solution was plated on LB agar plates. The plates were placed in an incubator at $37{ }^{\circ} \mathrm{C}$ for $24 \mathrm{~h}$, followed by colony counting. Antibacterial activity of sorbicillinoids against Gram-negative bacterium Proteus vulgaris ( $P$.vulgaris ), and Gram-positive bacteria Bacillussubtilis ( $B$. subtilis ) and Micrococcus luteus ( $M$. luteus ), were also tested in the same way.

\subsection{Intracellular ROS generation assay}

2,7-dichlorofluorescein diacetate (DCFH-DA) was applied to measure the generation of intracellular ROS. 0.5 $\mu \mathrm{L}$ DCFH-DA was added into $500 \mu \mathrm{L}$ bacteria suspension $\left(\mathrm{OD}_{600}=0.05\right)$, followed by incubation at 37 for 10 
min. After centrifugation at $8000 \mathrm{rpm}$ for $5 \mathrm{~min}$, bacteria were resuspended in $500 \mu \mathrm{L}$ water, supplemented with $5 \mu \mathrm{L}$ sorbicillinoids $(10 \mathrm{mg} / \mathrm{mL}$ for $S$. aureus and $40 \mathrm{mg} / \mathrm{mL}$ for $E$. coli $)$ dissolved in water. After incubation at 37 for $30 \mathrm{~min}$, the suspension was irradiated under UV light $\left(2 \mathrm{~mW} / \mathrm{cm}^{2}\right)$ for $30 \mathrm{~min}$. The fluorescence intensity was measured by a flow cytometer (NovoCyte 2060, ACEA, USA). Channel used for analyses was FITC with the excitation at $488 \mathrm{~nm}$.

\subsection{Agarose gel electrophoresis of bacterial genomic DNA}

The genomic DNA of bacteria was extracted with the Bacterial DNA kit which was bought from TIAGEN Biotech Co., Ltd. (Beijing, China). The bacteria cell $\left(1 \times 10^{6} \mathrm{CFU} / \mathrm{mL}\right)$ with different treatments as indicated in the antibacterial activity assay were collected by centrifugation at $8000 \mathrm{rpm}$ for $5 \mathrm{~min}$ and then washed twice with $0.9 \% \mathrm{NaCl}$. The genomic DNA was extracted according to manufacturer's instruction. Briefly, the bacterial cells were separately resuspended in $200 \mu \mathrm{L}$ GA buffer, $20 \mu \mathrm{L}$ proteinase $\mathrm{K}$ solution and $220 \mu \mathrm{L}$ GB buffer. After incubation at 70 for $10 \mathrm{~min}, 220 \mu \mathrm{L}$ ethanol was added into each sample. Then the solution was transferred to a spin column CB3 and washed with GD buffer and PW washing solution. After that, the genomic DNA was bound onto the spin column and then eluted with TE buffer. The extracted DNA was analyzed by electrophoresis in Tris Acetate-EDTA (TAE) buffer containing $0.8 \%$ agarose (w/v) for $50 \mathrm{~min}$ at $100 \mathrm{~V}$. The electrophoretic profiles were acquired with a Gel imaging system (Tanon 3500R, Shanghai, China).

\subsection{PI staining}

The bacterial cells $\left(1 \times 10^{6} \mathrm{CFU} / \mathrm{mL}\right)$ with different treatments as indicated in the antibacterial activity assay were incubated at 37 for $2 \mathrm{~h}$ and then collected by centrifugation at $8000 \mathrm{rpm}$ for $5 \mathrm{~min}$. After the centrifugation, the bacteria were stained with red-fluorescent nucleic acid stain (PI) for $30 \mathrm{~min}$. The bacteria samples were imaged using a confocal microscope (TCS SP8, Leica, Germany).

\subsection{Morphological characterization of bacteria}

Morphological characterization of bacteria was carried out with a scanning electron microscope (SEM, ULTRA Plus, Zeiss, Germany). The bacterial cells $\left(1 \times 10^{6} \mathrm{CFU} / \mathrm{mL}\right)$ with different treatments as indicated in the antibacterial activity assay were collected by centrifugation at $8000 \mathrm{rpm}$ for $5 \mathrm{~min}$ and then resuspended in $0.9 \% \mathrm{NaCl}$. After washing with $0.9 \% \mathrm{NaCl}$ three times, the bacteria cells were mixed with $2.5 \%(\mathrm{v} / \mathrm{v})$ glutaraldehyde for $12 \mathrm{~h}$ to fix the cell morphology, followed by dehydration using graded ethanol $(30 \%, 50 \%$, $70 \%, 90 \%$, and $95 \%$ ). Then the bacterial cells were resuspended in $100 \%$ ethanol and dripped in a silicon slide for SEM imaging.

\subsection{Cytotoxicity evaluation assay}

The toxicity of sorbicillinoids towards AT-II (normal human lung cell) by MTT assay. AT-II cells were cultivated in Dulbecco's modified eagle medium (DMEM), containing $10 \%$ fetal bovine serum, $100 \mathrm{U} / \mathrm{mL}$ of penicillin, and $100 \mu \mathrm{g} / \mathrm{mL}$ streptomycin in an incubator with $5 \% \mathrm{CO}_{2}$ at $37{ }^{\circ} \mathrm{C}$. The cells were seeded in a 96-well plate at a density of 5000 cells per well. After $24 \mathrm{~h}$ of culture, the cells were mixed with sorbicillinoids dissolved in DMEM at the final concentrations of 0 50,100, $150200,250,300,350,400$ and $450 \mu \mathrm{g} / \mathrm{mL}$, followed by $24 \mathrm{~h}$ of culture. Then, $10 \mu \mathrm{L}$ of MTT $(5 \mathrm{mg} / \mathrm{mL})$ was added into each well. After incubation for $4 \mathrm{~h}$, the solution was removed and $150 \mu \mathrm{L}$ DMSO was added into each cell. Then, the absorbance at $492 \mathrm{~nm}$ was measured with a microplate photometer (Multiskan FC, Thermo Fisher Scientific, USA).

\subsection{Hemolysis assay}

Fresh blood was collected from a healthy male mouse and restored in an anticoagulation tube to avoid the blood coagulation. Red blood cells (RBCs) were obtained from the blood by centrifugation at $2000 \mathrm{rpm}$ for $5 \mathrm{~min}$ and resuspended in $0.9 \% \mathrm{NaCl}$. The obtained RBCs were treated with different concentrations of sorbicillinoids $(50,100,200,250$, and $300 \mu \mathrm{g} / \mathrm{mL})$ for $2 \mathrm{~h}$ at $37{ }^{\circ} \mathrm{C}$, and centrifuged at $2000 \mathrm{rpm}$ for 5 min. Then the resultant supernatants were transferred to a 96 -well plate for the absorbance measurement at $492 \mathrm{~nm}$ with a microplate photometer (Multiskan FC, Thermo Fisher Scientific, USA). RBCs treated 
with phosphate-buffered saline (PBS) and triton X-100 were set as the negative control and positive control, respectively. The hemolysis percentage was calculated by the following formula:

Hemolysis $\%=[($ absorbance of samples - absorbance of negative control) $/$ (absorbance of positive control absorbance of negative control) $] \times 100 \%$.

\section{RESULTS AND DISCUSSION}

\subsection{Sorbicillinoids generated a high level of ${ }^{1} \mathrm{O}_{2}$ under UV light irradiation}

Sorbicillinoids was produced from the fermentation of the recombinant Trichoderma reesei (T. reesei ) strain ZC121 with an excellent sorbicillinoids production ability. The obtained sorbicillinoids mainly included sorbicillinol, bisvertinolone and oxosorbicillinol as identified by LC-MS (Li et al., 2018). Given that sorbicillinoids has great absorbance at $370 \mathrm{~nm}$ (Derntl et al., 2017), there is a possibility that sorbicillinoids can generate ${ }^{1} \mathrm{O}_{2}$ under light irradiation. To prove this, the ${ }^{1} \mathrm{O}_{2}$ generation ability of sorbicillinoids under the irradiation of both UV and white light was measured using a SOSG kit (Figure 1). Sorbicillinoids produced significant ${ }^{1} \mathrm{O}_{2}$ when irradiated with UV light. The produced ${ }^{1} \mathrm{O}_{2}$ was increased noticeably with the irradiation time increasing, being $300 \%$ that of UV alone at $30 \mathrm{~min}$. In contrast, when sorbicillinoids was exposed to white light for $30 \mathrm{~min}$, insignificant ${ }^{1} \mathrm{O}_{2}$ production was observed. $\mathrm{No}^{1} \mathrm{O}_{2}$ generation was observed for sorbicillinoids alone. This result confirmed our hypothesis that sorbicillinoids can synthesize ${ }^{1} \mathrm{O}_{2}$ in the presence of UV light, but not visible light. It is worth noting that ${ }^{1} \mathrm{O}_{2}$ is highly toxic to the microorganisms, serving as one major factor for APDT's antibacterial effect (Jia et al., 2017; Mao et al., 2017). Therefore, sorbicillinoids from T. reesei might be explored as a new PS for APDT to kill microorganisms.

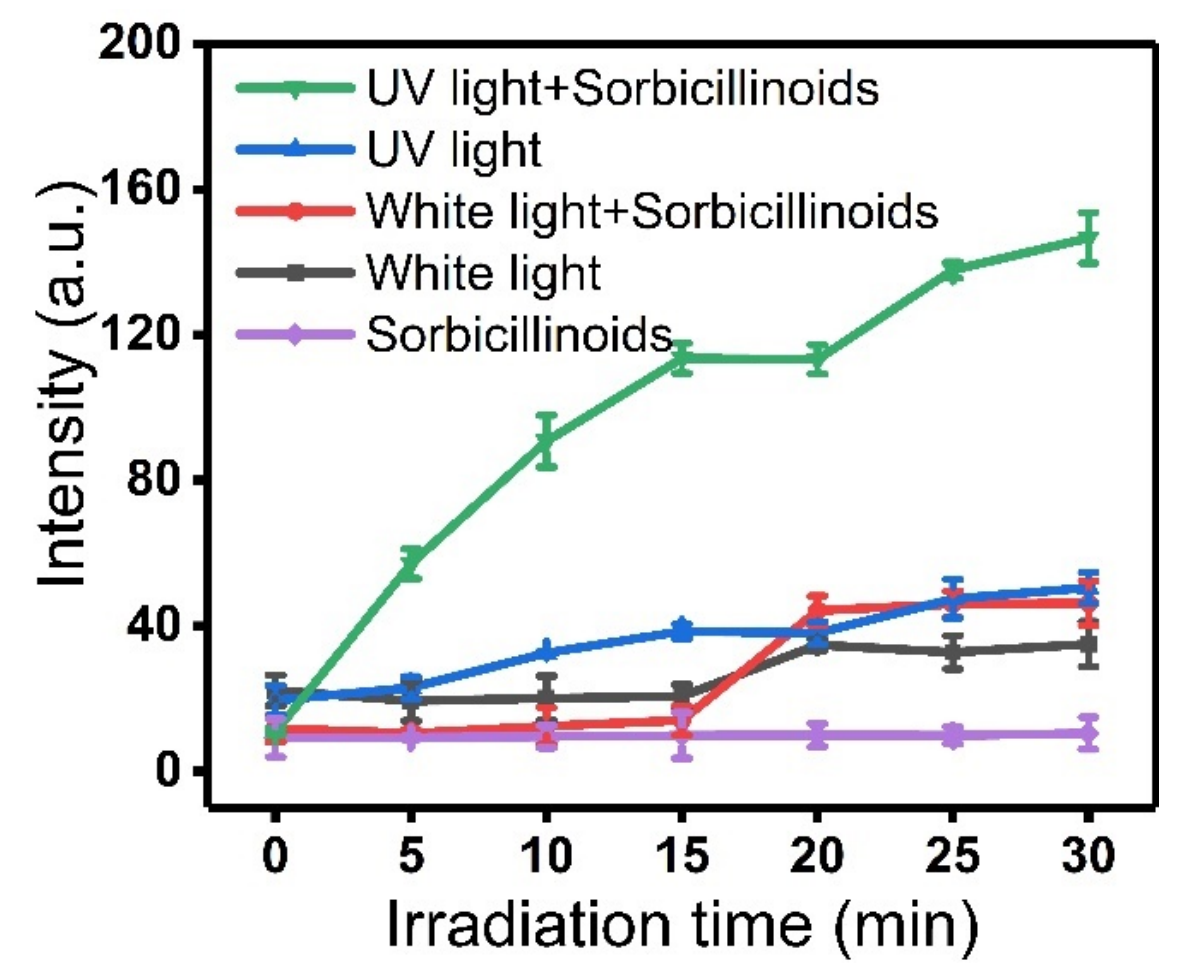

Figure 1. ${ }^{1} \mathrm{O}_{2}$ generation of sorbicillinoids in $0.9 \% \mathrm{NaCl}$ as measured by the fluorescence intensity changes of SOSG at $528 \mathrm{~nm}$ with the excitation wavelength of $504 \mathrm{~nm}$.

3.2 Sorbicillinoids showed photoinactivation against Gram-positive bacteria under nontoxic dose of UV irradiation 
Inspired by their excellent ${ }^{1} \mathrm{O}_{2}$ production ability under UV irradiation, we investigated the APDT ability of sorbicillinoids. $S$. aureus and $E$.coli representing Gram-positive and Gram-negative bacteria respectively, were incubated with different concentrations of sorbicillinoids in $1.5 \mathrm{~mL}$ sterilized centrifuge tubes, followed by UV light irradiation for $30 \mathrm{~min}$ (Figure 2). When irradiated under UV light, $S$. aureus was killed by $60.3 \%, 68.5 \%, 90.5 \%, 98.1 \%$, and $99.5 \%$ in the presence of $50,100,200,250$, and $300 \mu \mathrm{g} / \mathrm{mL}$ sorbicillinoids, respectively (Figure 2a and $2 \mathrm{~b}$ ). Conversely, no antibacterial effect of sorbicillinoids was observed on $E$. coli , even when the administrated concentration was increased up to $1000 \mu \mathrm{g} / \mathrm{mL}$ (Figure 2c and 2d). Sorbicillinoids or UV alone was non-toxic to both $S$. aureus and E. coli (Figure 2). The undetected antibacterial effect of UV light in this study is probably ascribed to the poor penetration ability of UV light through the plastic centrifuge tube (Ran et al., 2012). It appears that while the plastic is mitigating the intensity of incident UV light to the point where there is no cell death in the negative control, there is still enough incident UV light to sensitize sorbicillinoids to generate drastic ${ }^{1} \mathrm{O}_{2}$, leading to the killing of $S$. aureus .

Moreover, the UV-mediated APDT ability of sorbicillinoids was tested on another two Gram-positive bacteria $B$. subtilis and $M$. luteus, and another Gram-negative bacterium $P$.vulgaris . In the presence of $25,50,75$, 100,200 and $300 \mu \mathrm{g} / \mathrm{mL}$ sorbicillinoids and under UV light irradiation, B . subtilis was killed by $36.7 \%, 40.4 \%$, $61.4 \%, 89.3 \%$ and $98.5 \%$ and $98.9 \%$, respectively, whereas $M$. luteus was killed by $29.5 \%, 80.8 \%, 98.0 \%$, $99.7 \%$ and $99.9 \%$, respectively in the presence of 50, 100, 200, 250 and $300 \mu \mathrm{g} / \mathrm{mL}$ sorbicillinoids (Figure S1). By contrast, no antibacterial ability was observed against $P$.vulgaris (Figure S2) as it is in the case of $E$ .coli . Obviously, sorbicillinoids with the irradiation of nontoxic UV light can successfully kill Gram-positive bacteria, but not Gram-negative ones. This Gram-selective antibacterial ability of sorbicillinoids may be attributed to the different cell wall structures of Gram-positive bacteria and Gram-negative bacteria. It is well-known that compared to Gram-positive bacteria, Gram-negative bacteria have an outer membrane that lies outside of the plasma membrane, serving as a penetration barrier and protecting Gram-negative bacteria from antibiotics and PSs (Lam et al., 2016; Lien et al., 1968). This outer membrane may prevent sorbicillinoids from entering Gram-negative cells to realize APDT. The localization of PSs largely determines the efficiency of PDT, as the half-life of ${ }^{1} \mathrm{O}_{2}$ is very short $(<0.04 \mu \mathrm{s})$ and its action radius is only shorter than $0.02 \mu \mathrm{m}$ in the biological system (Moan and Berg, 1991). Therefore, despite it could produce abundant ${ }^{1} \mathrm{O}_{2}$ in the solution under UV light irradiation, the extracellular sorbicillinoids exhibited no bactericidal activity against Gram-negative bacteria. For Gram-positive bacteria without the outer membrane, the water-soluble sorbicillinoids with small molecular weight might readily diffuse through cell surface into the cytosol to exert APDT. 


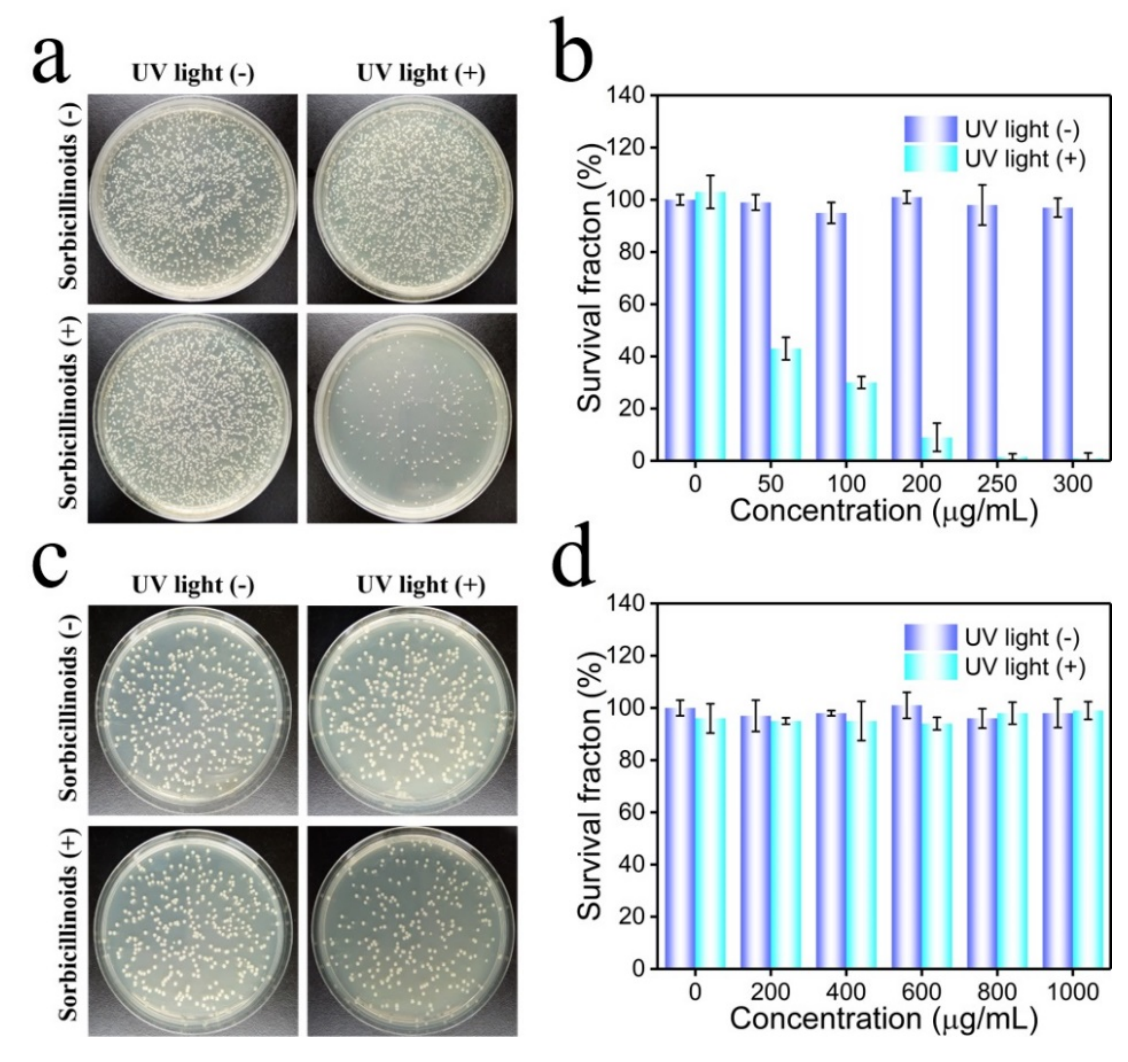

Figure 2 . The APDT ability of sorbicillinoids against $S$.aureus (a, b) and $E$. coli (c, d). Agar plate photographs of $S$. aureus (a) and $E$. coli (c) treated with sorbicillinoids under (no) UV light irradiation conditions. The corresponding dependence of bacterial survival fraction on the concentration of sorbicillinoids was measured $(b, d)$.

\subsection{Abnormally high level of intracellular ROS was found in S. aureus treated with sorbicilli- noids and UV irradiation, leading to DNA damage}

To evidence our speculation that sorbicillinoids enters Gram-positive bacteria to realize APDT, the generation of intracellular ROS was tested employing 2',7'-dichlorodihydrofluorescein diacetate (DCFH-DA) probe. DCFH-DA freely passes through the cell membrane into cells where it is hydrolyzed by intracellular esterase to form 2',7'-dichlorodihydrofluorescein (DCFH) that cannot penetrate the cell membrane and stay inside cells. DCFH is subsequently oxidized by the intracellular ROS into 2',7'-dichlorofluorescein (DCF) that has fluorescence. Neither DCFH-DA nor DCFH has fluorescence. Therefore, the level of ROS in the cells can be measured by detecting the fluorescence of DCF. After treated with sorbicillinoids and irradiated under UV light, the fluorescence intensity of $S$. aureus increased significantly by 5 times as compared to the untreated $S$.aureus, whereas no increasing fluorescence intensity was observed for $E$. coli (Figure 3a). This suggested that the treatment of sorbicillinoids with the irradiation of UV induced $S$.aureus to generate large sums of intracellular ROS, which might further damage biomacromolecules like proteins, DNA and lipids. This result matched well with the selective photoinactivation of sorbicillinoids against Gram-positive bacteria as we observed above.

Inspired by its ultra-high intracellular ROS level, DNA photocleavage of $S$. aureus with the treatment of sorbicillinoids and UV irradiation was detected by agarose gel electrophoresis (Figure 3b). There was a marked reduction of DNA for $S$. aureus treated with $100 \mu \mathrm{g} / \mathrm{mL}$ sorbicillinoids under UV light irradiation, indicating nucleic acid photocleavage took place in the treated bacterial cells. $S$. aureus treated with sor- 
bicillinoids or UV light alone did not display a reduction of DNA. On the contrary, sorbicillinoids did not result in observable DNA reduction in $E$. coli with or without UV light. Obviously, the unusually high intracellular ROS induced by sorbicillinoids upon UV irradiation caused cellular DNA damage in $S$. aureus

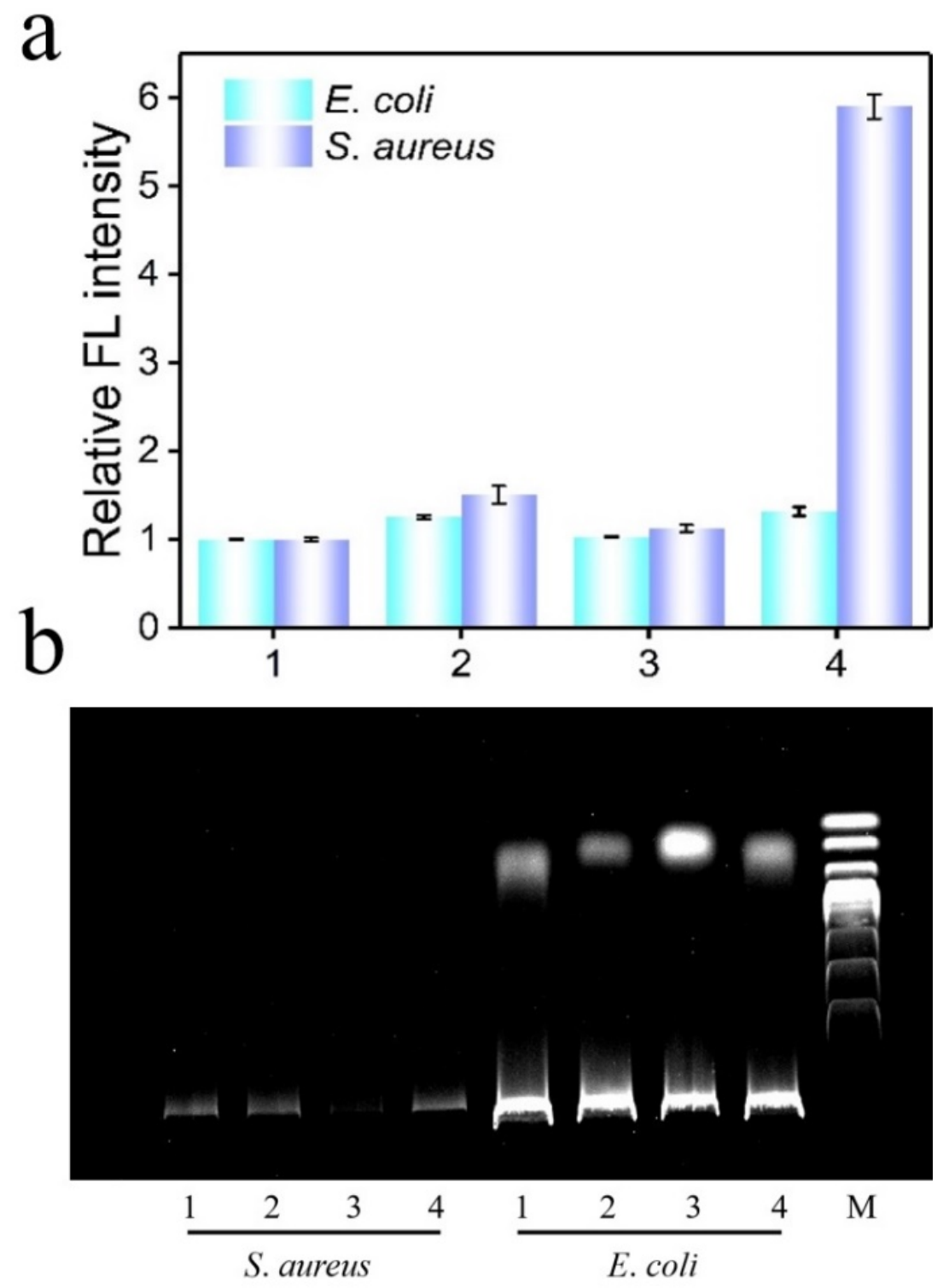

Figure 3 a) Generation of intracellular ROS in $S$.aureus and $E$. coli . b) Electrophoretic profiles of DNA extracted from $S$. aureus and $E$. coli . 1: no treatment; 2: UV light; 3: sorbicillinoids; 4: sorbicillinoids and UV light; M: molecular weight marker.

3.4 Sorbicillinoids with UV irradiation compromised cell semi-permeability of S. aureus without overt cell membrane disruption

Both DNA and cytoplasmic membrane are two crucial cellular components targeted by ROS in APDT (Ciep- 
lik et al., 2018). Therefore, the effect of sorbicillinoids on the cell membrane of $S$. aureus and $E$. coli was investigated using both propidium iodide (PI) staining and SEM imaging (Figure 4 and Figure S3). PI cannot penetrate into viable bacteria cells with complete membrane. Yet it can enter bacterial cells with damaged membrane to intercalate between the base pairs of the accessible double-stranded DNA and emit red fluorescence with the excitation at $580 \mathrm{~nm}$. $S$. aureus were dyed red by PI after the treatment of sorbicillinoids and UV irradiation (Figure 4a), demonstrating their membrane permeability was compromised. Nevertheless, no red fluorescence was observed in the irradiated $E$. coli cells in the presence of sorbicillinoids, showing their cell membrane was not affected (Figure S3a). This finding was consistent with that sorbicillinoids exhibited no APDT activity against E. coli . Similar to most classical PSs (Cieplik et al., 2018), sorbicillinoids induces oxidative damage to the cell membrane of $S$. aureus, contributing to its overall antimicrobial activity together with the high intracellular ROS level and the notable DNA photocleavage.

Furthermore, SEM experiments were carried out to monitor the impact of sorbicillinoids on the morphology of bacterial surface. No noticeable morphology change was found in the SEM pictures of the irradiated $S$. aureus (Figure 4b) andE. coli (Figure S3b), including wrinkles, holes or leaked intracellular substances as reported previously for some photodynamic antibacterial materials (Jia et al., 2017; Mao et al., 2019). Sorbicillinoids killed $S$. aureus without overt cell membrane disruption, as in the case of other PSs like EPS-RB NPs ( $\mathrm{Li}$ et al., 2018). Taken together, sorbicillinoids can readily diffuse through the cell wall of Gram-positive bacteria into the cells. When irradiated under UV light, it produced large sums of intracellular ROS, thereby targeting and destroying both cytoplasmic membrane and DNA to achieve APDT effect. This does not happen to Gram-negative bacteria due to their distinctive outer membrane that is an extra effective penetration barrier to block sorbicillinoids out of cells.

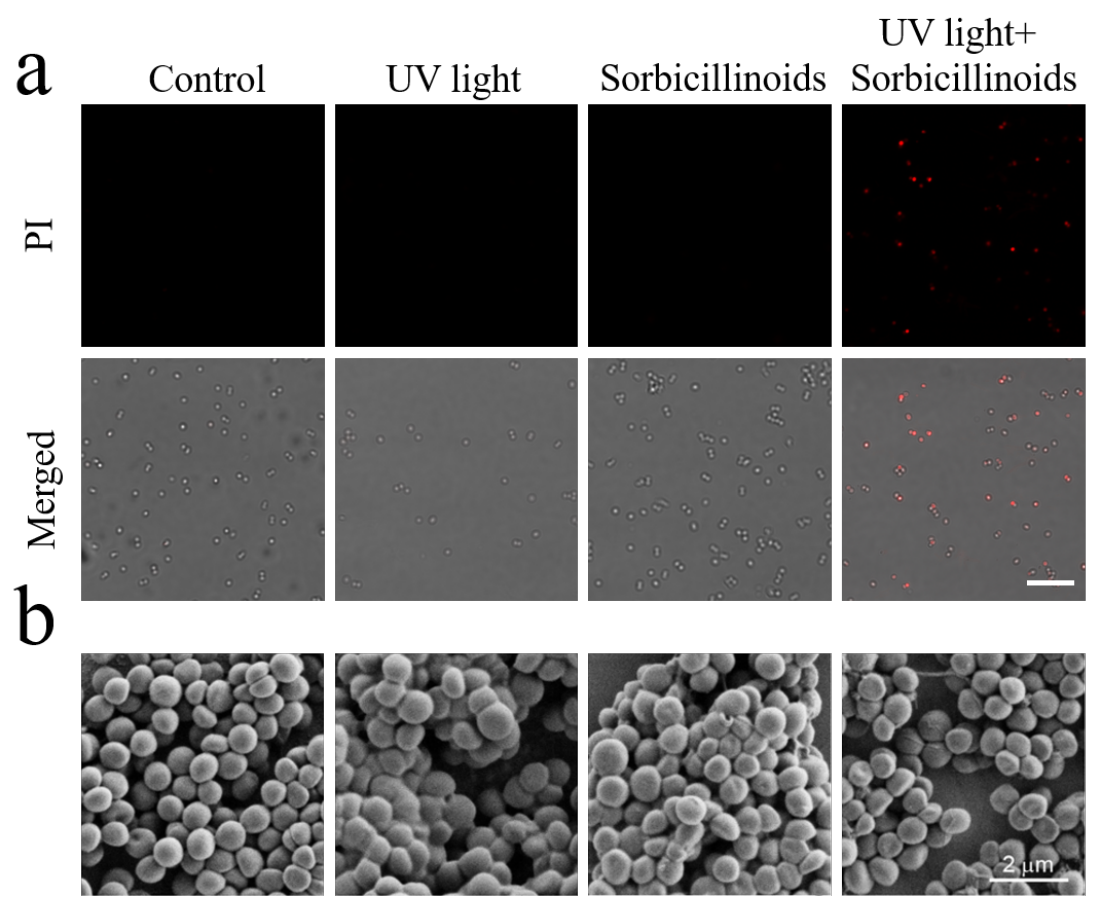

Figure 4 a) Confocal fluorescence images of $S$. aureus that was incubated with PI after different treatments as indicated in the figure. Bacteria with damaged cell membrane would be stained by PI, showing red fluorescence. (scale bar $=10 \mu \mathrm{m}$ ). b) the corresponding SEM images were also taken.

\subsection{Sorbicillinoids-mediated APDT exhibited good biocompatibility}

Last but not least, the biocompatibility of sorbicillinoids was assessed by the cytotoxicity measurement and 
hemolysis assay (Figure 5). Sorbicillinoids showed a little cytotoxicity to AT-II cells at $400 \mu \mathrm{g} / \mathrm{mL}$ (Figure 5a) that was higher than its bactericidal concentrations for $S$. aureus (Figure 4a), B . subtilis (Figure S1a) and $M$. luteus (Figure S1b). When the concentration of sorbicillinoids was increased to $450 \mu \mathrm{g} / \mathrm{mL}$, more than $85 \%$ of AT-II cells remained alive, demonstrating a high safety of sorbicillinoids (Figure 5a). More importantly, even under the irradiation of UV light, only a slight decrease of the cell viability was found with $>75.66 \%$ AT-II cells alive when the concentration of sorbicillinoids was increased up to $450 \mu \mathrm{g} / \mathrm{mL}$. Thus, sorbicillinoids did not induce marked dark toxicity or phototoxicity to AT-II cells. On the other hand, only $0.89 \%$ hemolysis was observed with the treatment of $300 \mu \mathrm{g} / \mathrm{mL}$ sorbicillinoids (Figure $5 \mathrm{~b}$ and Figure S4). Sorbicillinoids show excellent biocompatibility, which is of benefit to their future practical applications in clinic.
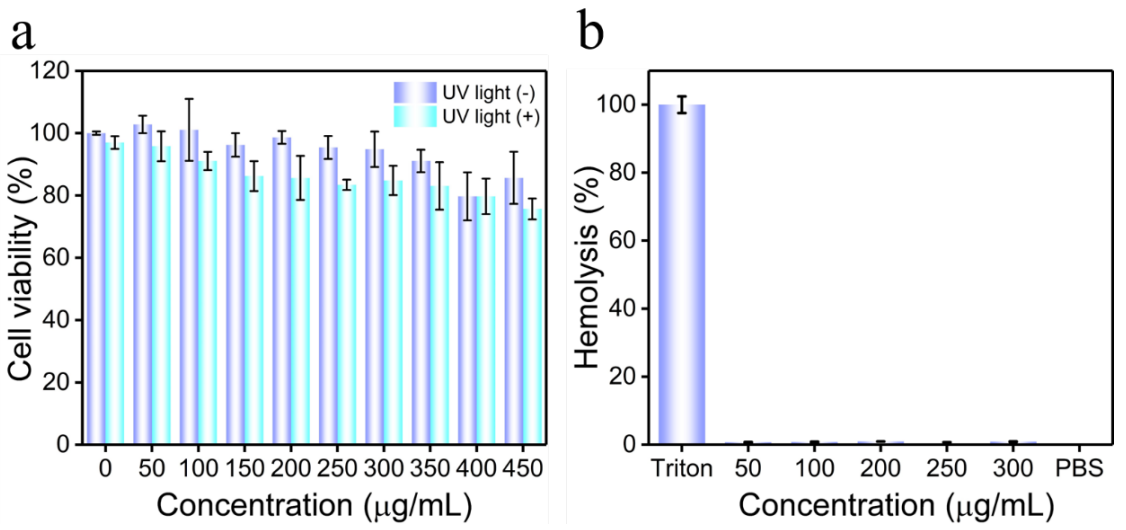

Figure 5 . Biocompatibility evaluation of sorbicillinoids. a) Viabilities of AT-II cells in the presence of different concentrations of sorbicillinoids with and without UV light. b) Hemolysis rates of RBCs after incubation with various concentrations of sorbicillinoids. RBCs in Triton X-100 and PBS were set as the positive and negative controls, respectively.

\section{CONCLUSIONS}

We discovered a novel water-soluble PS (sorbicillinoids) from filamentous fungus Trichoderma reesei by microbial fermentation. The obtained sorbicillinoids could transform oxygen molecules to ${ }^{1} \mathrm{O}_{2}$ effectively under nontoxic dose of UV irradiation. As a result, the irradiated sorbicillinoids by nontoxic dose of UV light displayed photoinactivation activity against Gram-positive bacteria including $S$.aureus, $B$. subtilis and $M$. luteus . $S$.aureus treated with sorbicillinoids and UV light irradiation exhibited high level production of intracellular ROS, marked DNA reduction, and damaged cell membrane without observable cell morphology change, leading to the cell death of Gram-positive bacteria. Sorbicillinoids can be obtained on a large scale through microbial fermentation by $T$. reesei or other microorganisms, which is sustainable, environmentallyfriendly and low cost. This newly-discovered PS has good water solubility. Furthermore, they displayed good biocompatibility. Therefore, sorbicillinoids-based APDT presents a potential platform for combating pathogen-related diseases.

\section{ACKNOWLEDGMENTS}

This work was supported by grants from the National Natural Science Foundation of China (31700040), and the Fundamental Research Funds for the Central Universities.

\section{CONFLICT OF INTERESTS}

The authors declare that they have no known competing financial interests or personal relationships that could have appeared to influence the work reported in this paper. 


\section{REFERENCES}

Abe, N., and Hirota, A. (2002). Chemical Studies of the Radical Scavenging Mechanism of Bisorbicillinol Using the 1,1-Diphenyl-2-Picrylhydrazyl Radical. Chemical Communications , 6, 662-663. https://doi.org/10.1039/B200039N

Abrahamse, H., and Hamblin, M.R. (2016). New Photosensitizers for Photodynamic Therapy. Biochemical Journal , 473(4), 347-364. https://doi.org/10.1042/BJ20150942

Almeida-Marrero, V., van de Winckel, E., Anaya-Plaza, E., Torres, T., and de la Escosura, A. (2018). Porphyrinoid Biohybrid Materials as an Emerging Toolbox for Biomedical Light Management. Chemical Society Reviews , 47(19), 7369-7400. https://doi.org/10.1039/C7CS00554G

Alves, E., Faustino, M.A.F., Tomé, J.P.C., Neves, M.G.P.M.S., Tomé, A.C., Cavaleiro, J.A.S., Cunha, Â., Gomes, N.C.M., and Almeida, A. (2013). Nucleic Acid Changes during Photodynamic Inactivation of Bacteria by Cationic Porphyrins. Bioorganic $\& 3$ Medicinal Chemistry , 21(14), 4311-4318. https://doi.org/10.1016/j.bmc.2013.04.065

Cieplik, F., Deng, D.M., Crielaard, W., Buchalla, W., Hellwig, E., Al-Ahmad, A., and Maisch, T. (2018). Antimicrobial Photodynamic Therapy - What We Know and What We Don't. Critical Reviews in Microbiology , 44(5), 571-589. https://doi.org/10.1080/1040841X.2018.1467876

Davies, M.J. (2003). Singlet Oxygen-Mediated Damage to Proteins and Its Consequences. Biochemical and Biophysical Research Communications , 305(3), 761-770. https://doi.org/10.1016/S0006-291X(03)00817-9

Derntl, C., Kluger, B., Bueschl, C., Schuhmacher, R., Mach, R.L., and Mach-Aigner, A.R. (2017). Transcription Factor Xpp1 Is a Switch between Primary and Secondary Fungal Metabolism. Proceedings of the National Academy of Sciences of the United States of America, 114(4), 560-569. https://doi.org/10.1073/pnas.1609348114

Fischbach, M.A., and Walsh, C.T. (2009). Antibiotics for Emerging Pathogens. Science, 325(5944), 10891093. doi:10.1126/science.1176667

García, I., Ballesta, S., Gilaberte, Y., Rezusta, A., and Pascual, Á. (2015). Antimicrobial Photodynamic Activity of Hypericin against Methicillin-Susceptible and Resistant Staphylococcusaureus Biofilms. Future Microbiology , 10(3), 347-356. https://doi.org/10.2217/fmb.14.114

Guo, W.Q., Zhang, Z.Z., Zhu, T.J., Gu, Q.Q., and Li, D.H. (2015). Penicyclones A-E,Antibacterial Polyketides from the Deep-Sea-Derived Fungus Penicillium sp. F23-2.Journal of Natural Products, 78(11), 2699-2703. https://doi.org/10.1021/acs.jnatprod.5b00655

Hamblin, M.R., and Hasan, T. (2004). Photodynamic Therapy: A New Antimicrobial Approach to Infectious Disease? Photochemical \& Photobiological Sciences , 3(5), 436-450. https://doi.org/10.1039/B311900A

Han, K., Lei, Q., Wang, S.B., Hu, J.J., Qiu, W.X., Zhu, J.Y., Yin, W.N., Luo, X., and Zhang, X.Z. (2015). Dual-Stage-Light-Guided Tumor Inhibition by Mitochondria-Targeted Photodynamic Therapy. Advanced Functional Materials , 25(20), 2961-2971. https://doi.org/10.1002/adfm.201500590

Harned, A.M., and Volp, K.A. (2011). The Sorbicillinoid Family of Natural Products: Isolation, Biosynthesis, and Synthetic Studies.Natural Product Reports , 28(11), 1790-1810. https://doi.org/10.1039/C1NP00039J

Huh, A.J., and Kwon, Y.J. (2011). "Nanoantibiotics": A New Paradigm for Treating Infectious Diseases Using Nanomaterials in the Antibiotics Resistant Era. Journal of Controlled Release , 156(2), 128-145. https://doi.org/10.1016/j.jconrel.2011.07.002

Jia, H.R., Zhu, Y.X., Chen, Z., and Wu, F.G. (2017). Cholesterol-Assisted Bacterial Cell Surface Engineering for Photodynamic Inactivation of Gram-Positive and Gram-Negative Bacteria.ACS Applied Materials $\mathscr{B}$ Interfaces, 9(19), 15943-15951. https://doi.org/10.1021/acsami.7b02562

Jones, K.E., Patel, N.G., Levy, M.A., Storeygard, A., Balk, D., Gittleman, J.L., and Daszak, P. (2008). Global Trends in Emerging Infectious Diseases. Nature , 451, 990-993. https://doi.org/10.1038/nature06536 
Kawahara, T., Takagi, M., and Shin-ya, K. (2012). JBIR-124: A Novel Antioxidative Agent from a Marine Sponge-Derived FungusPenicillium citrinum SpI080624G1f01. The Journal of Antibiotics , 65, 45-47. https://doi.org/10.1038/ja.2011.98

Lai, D.W., Meng, J.J., Zhang, X.P., Xu, D., Dai, J.G., and Zhou, L.G. (2019). Ustilobisorbicillinol A, a Cytotoxic Sorbyl-Containing Aromatic Polyketide from Ustilaginoidea virens .Organic Letters, 21(5), 13111314. https://doi.org/10.1021/acs.orglett.8b04101

Lam, S.J., O'Brien-Simpson, N.M., Pantarat, N., Sulistio, A., Wong, E.H.H., Chen, Y.Y., Lenzo, J.C., Holden, J.A., Blencowe, A., Reynolds, E.C., and Qiao, G.G. (2016). Combating Multidrug-Resistant Gram-Negative Bacteria with Structurally Nanoengineered Antimicrobial Peptide Polymers. Nature Microbiology, 1, 16162. https://doi.org/10.1038/nmicrobiol.2016.162

Levy, S.B., and Marshall, B. (2004). Antibacterial Resistance Worldwide: Causes, Challenges and Responses. Nature medicine , 10, 122-129. https://doi.org/10.1038/nm1145

Li, C.C., Lin, F.M., Sun, W., Wu, F.G., Yang, H., Lv, R.J., Zhu, Y.X., Jia, H.R., Wang, C., Gao, G., and Chen, Z. (2018). Self-Assembled Rose Bengal-Exopolysaccharide Nanoparticles for Improved Photodynamic Inactivation of Bacteria by Enhancing Singlet Oxygen Generation Directly in the Solution. ACS Applied Materials $\&$ Interfaces, 10(19), 16715-16722. https://doi.org/10.1021/acsami.8b01545

Li, C.C., Lin, F.M., Sun, W., Yuan, S.X., Zhou, Z.H., Wu, F.G., and Chen, Z. (2018). Constitutive Hyperproduction of Sorbicillinoids in Trichoderma reesei ZC121.Biotechnology for Biofuels, 11, 291. https://doi.org/10.1186/s13068018-1296-4

Lien, E.J.C., Hansch, C., and Anderson, S.M. (1968). Structure-Activity Correlations for Antibacterial Agents on Gram-Positive and Gram-Negative Cells. Journal of Medicinal Chemistry, 11(3), 430-441. https://doi.org/10.1021/jm00309a004

Liu, L.H., Xu, K.J., Wang, H.Y., Tan, J.P.K., Fan, W.M., Venkatraman, S.S., Li, L.J., and Yang, Y.Y. (2009). Self-Assembled Cationic Peptide Nanoparticles as an Efficient Antimicrobial Agent.Nature Nanotechnology, 4, 457-463. https://doi.org/10.1038/nnano.2009.153

Liu, Y., Qin, R., Zaat, S.A.J., Breukink, E., and Heger, M. (2015). Antibacterial Photodynamic Therapy: Overview of a Promising Approach to Fight Antibiotic-Resistant Bacterial Infections. Journal of Clinical and Translational Research , 1(3), 140-167. http://dx.doi.org/10.18053/jctres.201503.002

Maisch, T., Eichner, A., Späth, A., Gollmer, A., König, B., Regensburger, J., and Bäumler, W. (2014). Fast and Effective Photodynamic Inactivation of Multiresistant Bacteria by Cationic Riboflavin Derivatives. PLoS One , 9(12), 111792. https://doi.org/10.1371/journal.pone.0111792

Malcher, M., Volodkin, D., Heurtault, B., André, P., Schaaf, P., Möhwald, H., Voegel,J.C., Sokolowski, A., Ball, V., Boulmedais, F., and Frisch, B. (2008). Embedded Silver Ions-Containing Liposomes in Polyelectrolyte Multilayers: Cargos Films forAntibacterial Agents. Langmuir , 24(18), 10209-10215. https://doi.org/10.1021/la8014755

Mao, C.Y., Xiang, Y.M., Liu, X.M., Cui, Z.D., Yang, X.J., Yeung, K.W.K., Pan, H.B., Wang, X.B., Chu, P.K., and $\mathrm{Wu}$, S.L. (2017). Photo-Inspired Antibacterial Activity and Wound Healing Acceleration by Hydrogel Embedded with Ag/Ag@AgCl/ZnO Nanostructures. ACS Nano , 11(9), 9010-9021. https://doi.org/10.1021/acsnano.7b03513

Mao, C.Y., Xiang, Y.M., Liu, X.M., Zheng, Y.F., Yeung, K.W.K., Cui, Z.D., Yang, X.J., Li, Z.Y., Liang, Y.Q., Zhu, S.L., and Wu, S.L. (2019). Local Photothermal/Photodynamic Synergistic Therapy by Disrupting Bacterial Membrane To Accelerate Reactive Oxygen Species Permeation and Protein Leakage. ACS Applied Materials $\&$ Interfaces, 11(19), 17902-17914. https://doi.org/10.1021/acsami.9b05787

Meng, J.J., Cheng, W., Heydari, H., Wang, B., Zhu, K., Konuklugil, B., and Lin, W.H. (2018). SorbicillinoidBased Metabolites from a Sponge-Derived Fungus Trichoderma saturnisporum .Marine Drugs , 16(7), 226. https://doi.org/10.3390/md16070226 
Meng, J.J., Gu, G., Dang, P.Q., Zhang, X.P., Wang, W.X., Dai, J.G., Liu, Y., Lai, D.W., and Zhou, L.G. (2019). Sorbicillinoids from the Fungus Ustilaginoidea virens and Their Phytotoxic, Cytotoxic, and Antimicrobial Activities. Frontiers in Chemistry , 7, 435. https://doi.org/10.3389/fchem.2019.00435

Meng, J.J., Wang, X.H., Xu, D., Fu, X.X., Zhang, X.P., Lai, D.W., Zhou, L.G., and Zhang, G.Z. (2016). Sorbicillinoids from Fungi and Their Bioactivities. Molecules21(6), 715. https://doi.org/10.3390/molecules21060715

Minty, J.J., Singer, M.E., Scholz, S.A., Bae, C.H., Ahn, J.H., Foster, C.E., Liao, J.C., and Lin, X.N. (2013). Design and Characterization of Synthetic Fungal-Bacterial Consortia for Direct Production of Isobutanol from Cellulosic Biomass. Proceedings of the National Academy of Sciences of the United States of America , 110(36), 14592-14597. https://doi.org/10.1073/pnas.1218447110

Moan, J., and Berg, K. (1991). The Photodegradation of Porphyrins in Cells Can Be Used to Estimate the Lifetime of Singlet Oxygen.Photochemistry und Photobiology , 53(4), 549-553. https://doi.org/10.1111/j.17511097.1991.tb03669.x

Parthasarathy, A., Pappas, H.C., Hill, E.H., Huang, Y., Whitten, D.G., and Schanze, K.S. (2015). Conjugated Polyelectrolytes with Imidazolium Solubilizing Groups. Properties and Application to Photodynamic Inactivation of Bacteria.ACS Applied Materials \& Interfaces, 7(51), 28027-28034. https://doi.org/10.1021/acsami.5b02771

Ran, C.Z., Zhang, Z.D., Hooker, J., and Moore, A. (2012). In Vivo Photoactivation Without "Light": Use of Cherenkov Radiation to Overcome the Penetration Limit of Light.Molecular Imaging and Biology, 14, 156-162. https://doi.org/10.1007/s11307-011-0489-z

Ran, H.H., Cheng, X.T., Bao, Y.W., Hua, X.W., Gao, G., Zhang, X.D., Jiang, Y.W., Zhu, Y.X., and Wu, F.G. (2019). Multifunctional Quaternized Carbon Dots with Enhanced Biofilm Penetration and Eradication Efficiencies. Journal of Materials Chemistry B , 7(33), 5104-5114. https://doi.org/10.1039/C9TB00681H

Ravikumar, M., Raghav, D., Rathinasamy, K., Kathiravan, A., and Mothi, E.M. (2018). DNA Targeting Long-Chain Alkoxy Appended Tin(IV) Porphyrin Scaffolds: Photophysical and Antimicrobial PDT Investigations.ACS Applied Bio Materials, 1(5), 1705-1716. https://doi.org/10.1021/acsabm.8b00507

Taubes, G. (2008). The Bacteria Fight Back. Science, 321(5887), 356-361. doi:10.1126/science.321.5887.356

Tenover, F.C. (2006). Mechanisms of Antimicrobial Resistance in Bacteria. The American Journal of Medicine , 119(6), 3-10. https://doi.org/10.1016/j.amjmed.2006.03.011

Theuretzbacher, U. (2013). Global Antibacterial Resistance: The Never-Ending Story. Journal of Global Antimicrobial Resistance , 1(2), 63-69. https://doi.org/10.1016/j.jgar.2013.03.010

Tonon, C.C., Paschoal, M.A., Correia, M., Spolidório, D.M.P., Bagnato, V.S., Giusti, J.S.M., and SantosPinto, L. (2015). Comparative Effects of Photodynamic Therapy Mediated by Curcumin on Standard and Clinical Isolate ofStreptococcus mutans. The Journal of Contemporary Dental Practice , 16(1), 1-6. doi:10.5005/jp-journals-10024-1626

Wegener, M., Hansen, M.J., Driessen, A.J.M., Szymanski, W., and Feringa, B.L. (2017). Photocontrol of Antibacterial Activity: Shifting from UV to Red Light Activation. Journal of the American Chemical Society, 139(49), 17979-17986. https://doi.org/10.1021/jacs.7b09281

Wu, S.M., Li, A.H., Zhao, X.Y., Zhang, C.L., Yu, B.R., Zhao, N.N., and Xu, F.J. (2019). Silica-Coated GoldSilver Nanocages as Photothermal Antibacterial Agents for Combined Anti-Infective Therapy.ACS Applied Materials $\&$ Interfaces, 11(19), 17177-17183. https://doi.org/10.1021/acsami.9b01149

Yang, J.J., Zhang, X.D., Ma, Y.H., Gao, G., Chen, X.K., Jia, H.R., Li, Y.H., Chen, Z., and Wu, F.G. (2016). Carbon Dot-Based Platform for Simultaneous Bacterial Distinguishment and Antibacterial Applications. ACS Applied Materials $\&$ Interfaces, 8(47), 32170-32181. https://doi.org/10.1021/acsami.6b10398

Zhang, C., Gao, F., Wu, W., Qiu, W.X., Zhang, L., Li, R.Q., Zhuang, Z.N., Yu, W.Y., Cheng, H., and Zhang, X.Z. (2019). Enzyme-Driven Membrane-Targeted Chimeric Peptide for Enhanced Tumor Photodynamic 
Immunotherapy. ACS Nano , 13(10), 11249-11262. https://doi.org/10.1021/acsnano.9b04315

Zhao, Y., Dai, X.M., Wei, X.S., Yu, Y.J., Chen, X.L., Zhang, X.G., and Li, C.X. (2018). Near-Infrared LightActivated Thermosensitive Liposomes as Efficient Agents for Photothermal and Antibiotic Synergistic Therapy of Bacterial Biofilm. ACS Applied Materials \& Interfaces, 10(17), 14426-14437. https://doi.org/10.1021/acsami.8b01327

Zhenjun, D., and Lown, J.W. (1990). Hypocrellins and Their Use in Photosensitization.Photochemistry and Photobiology , 52(3), 609-616. https://doi.org/10.1111/j.1751-1097.1990.tb01807.x

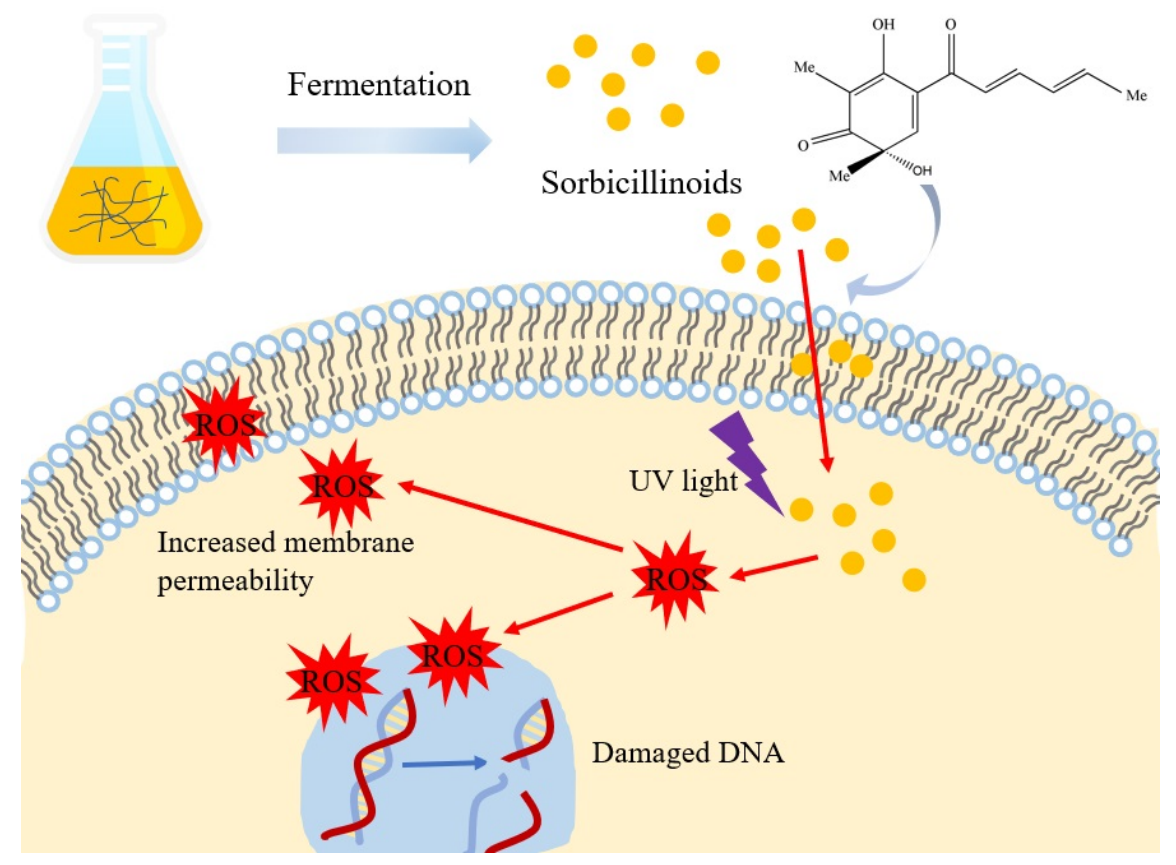



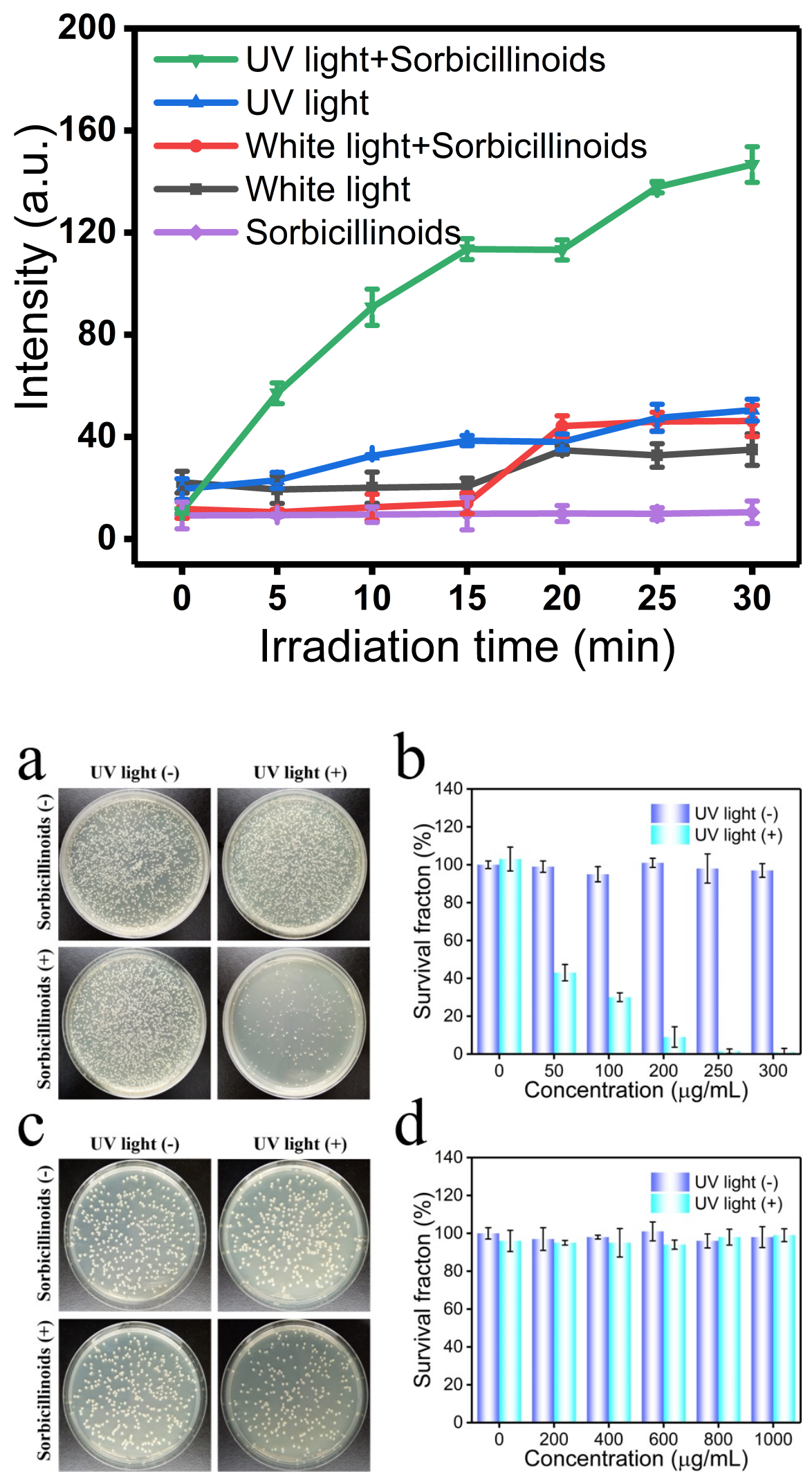

b

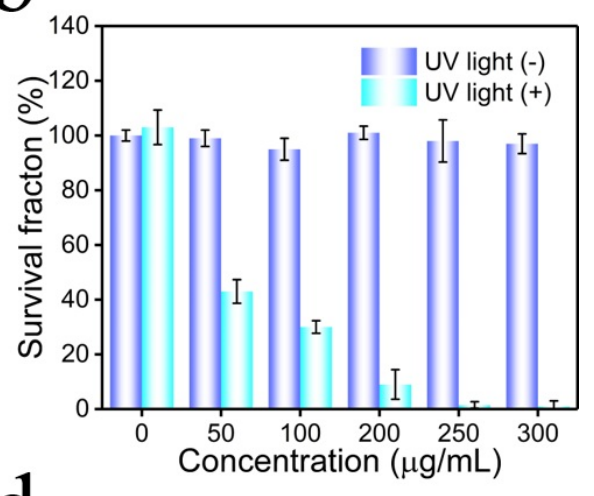

d

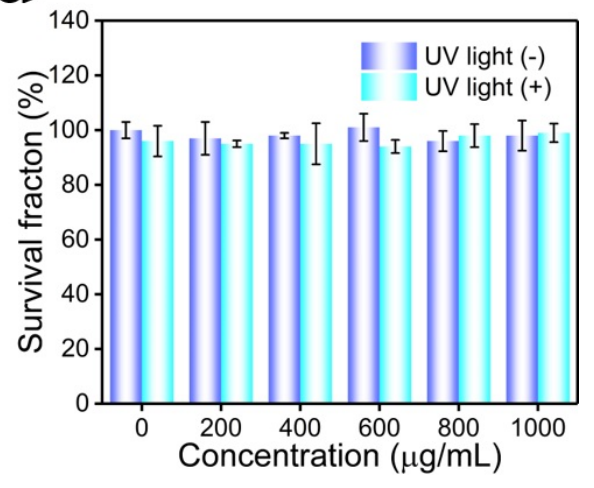




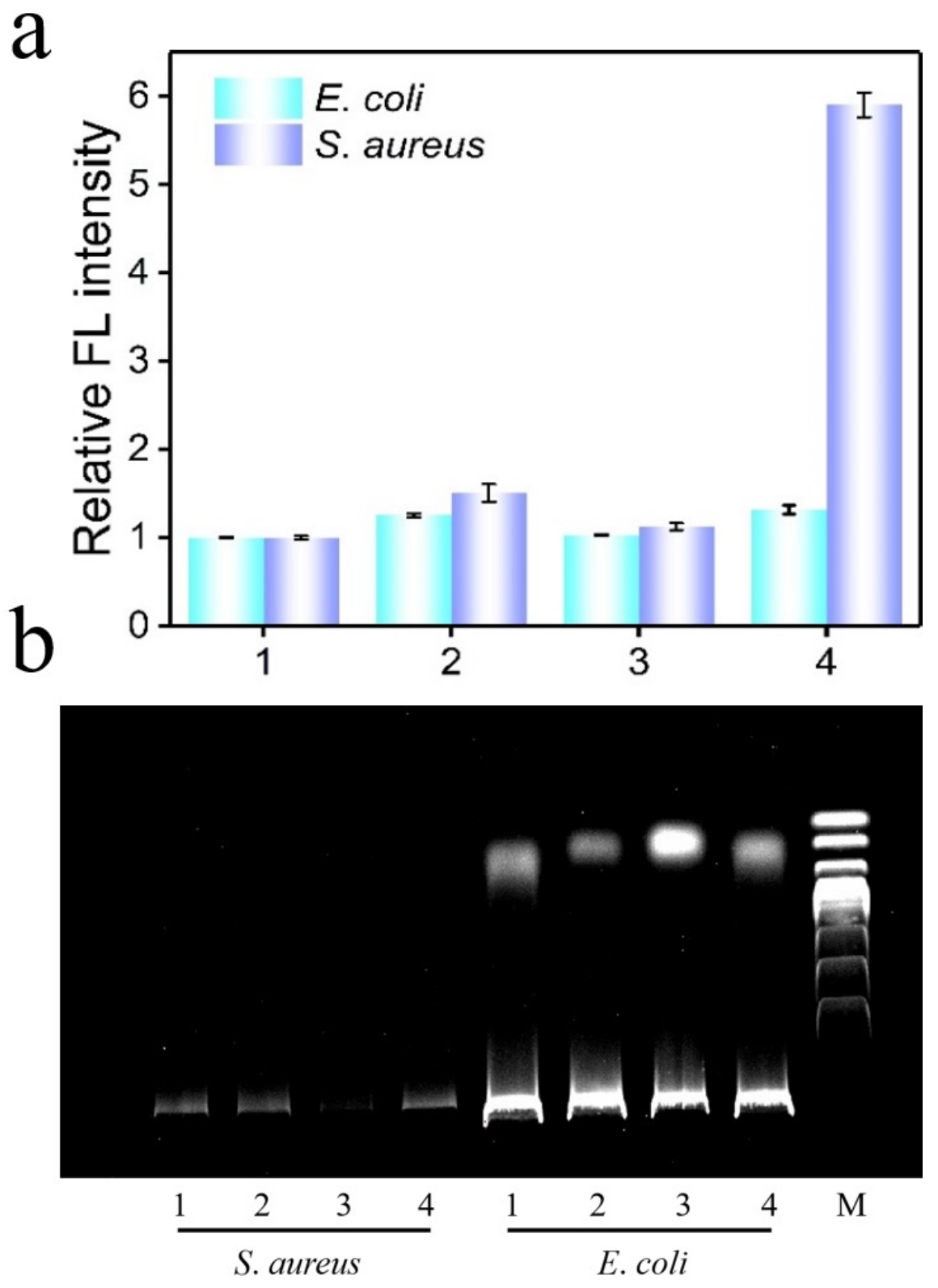


UV light+
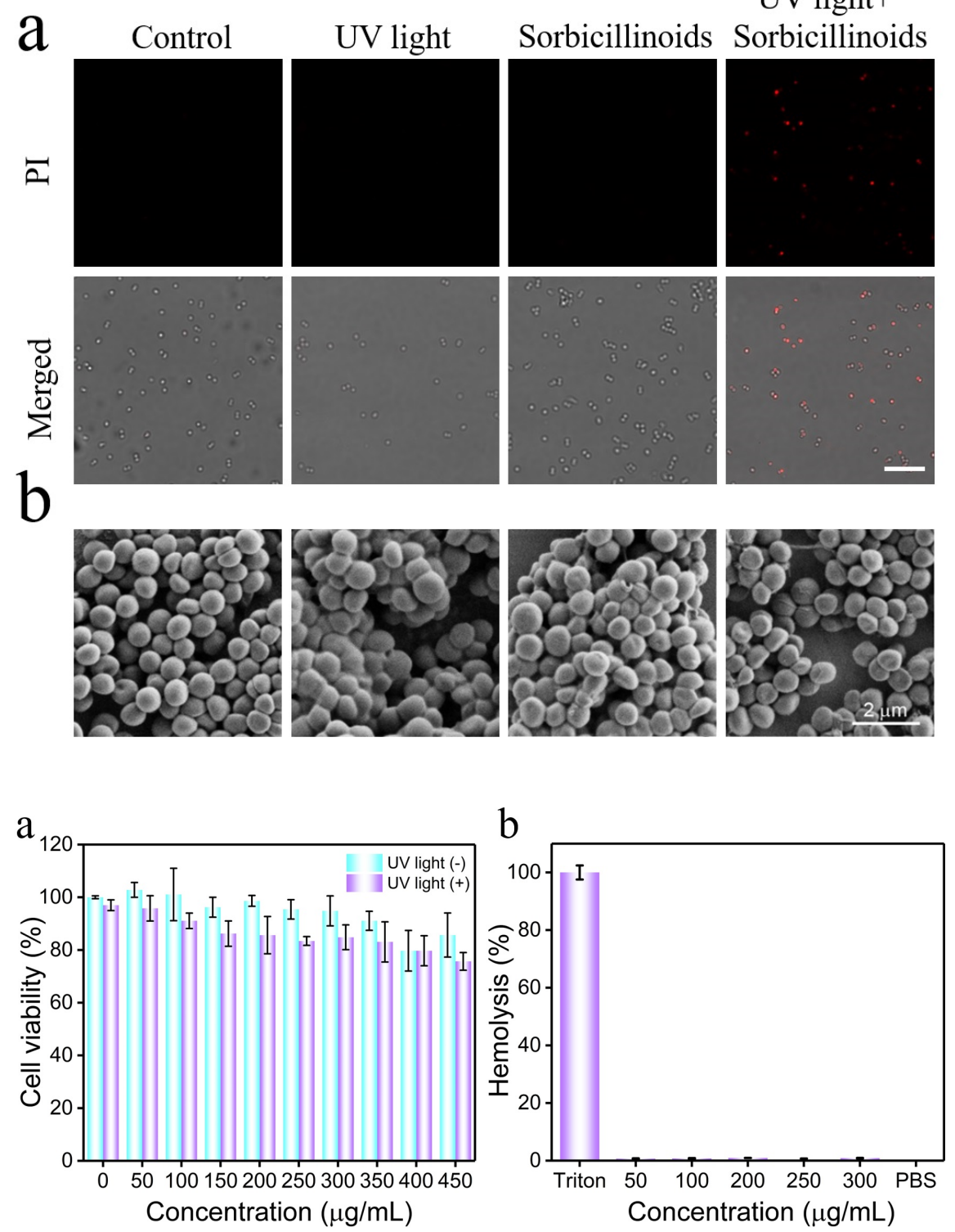

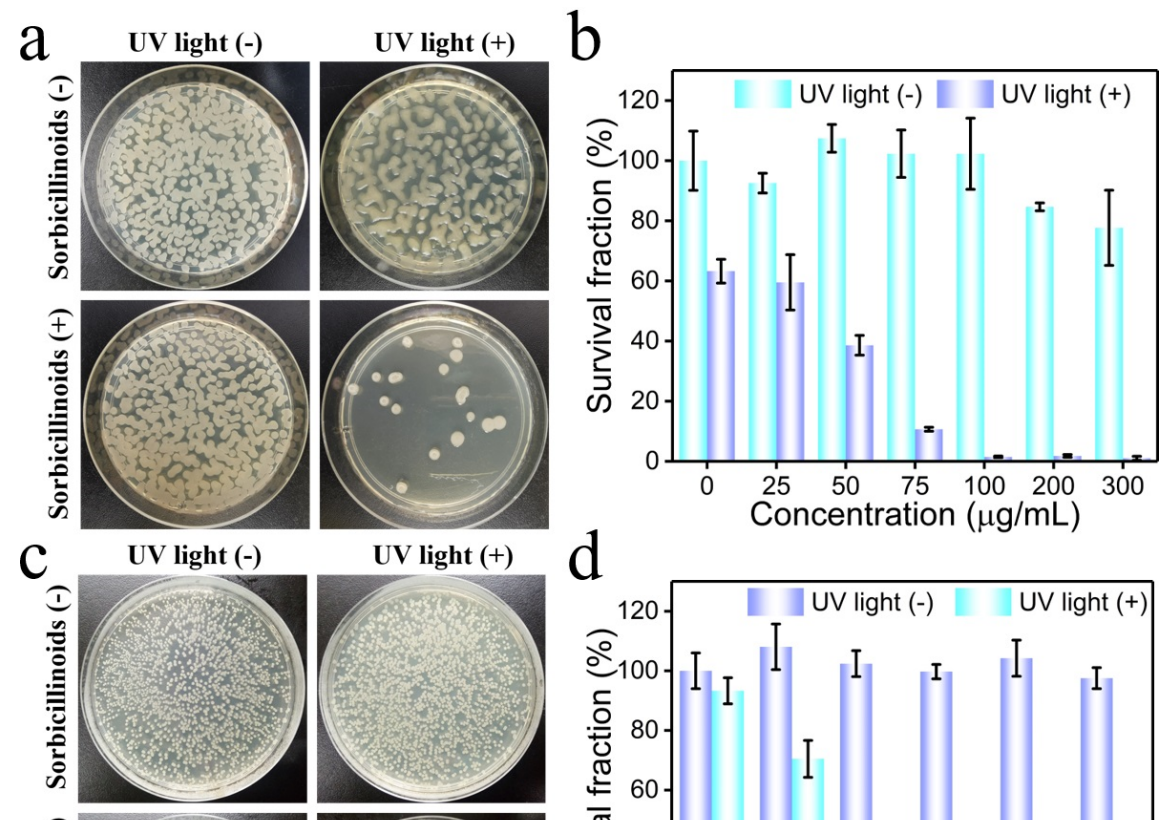

UV light (+)
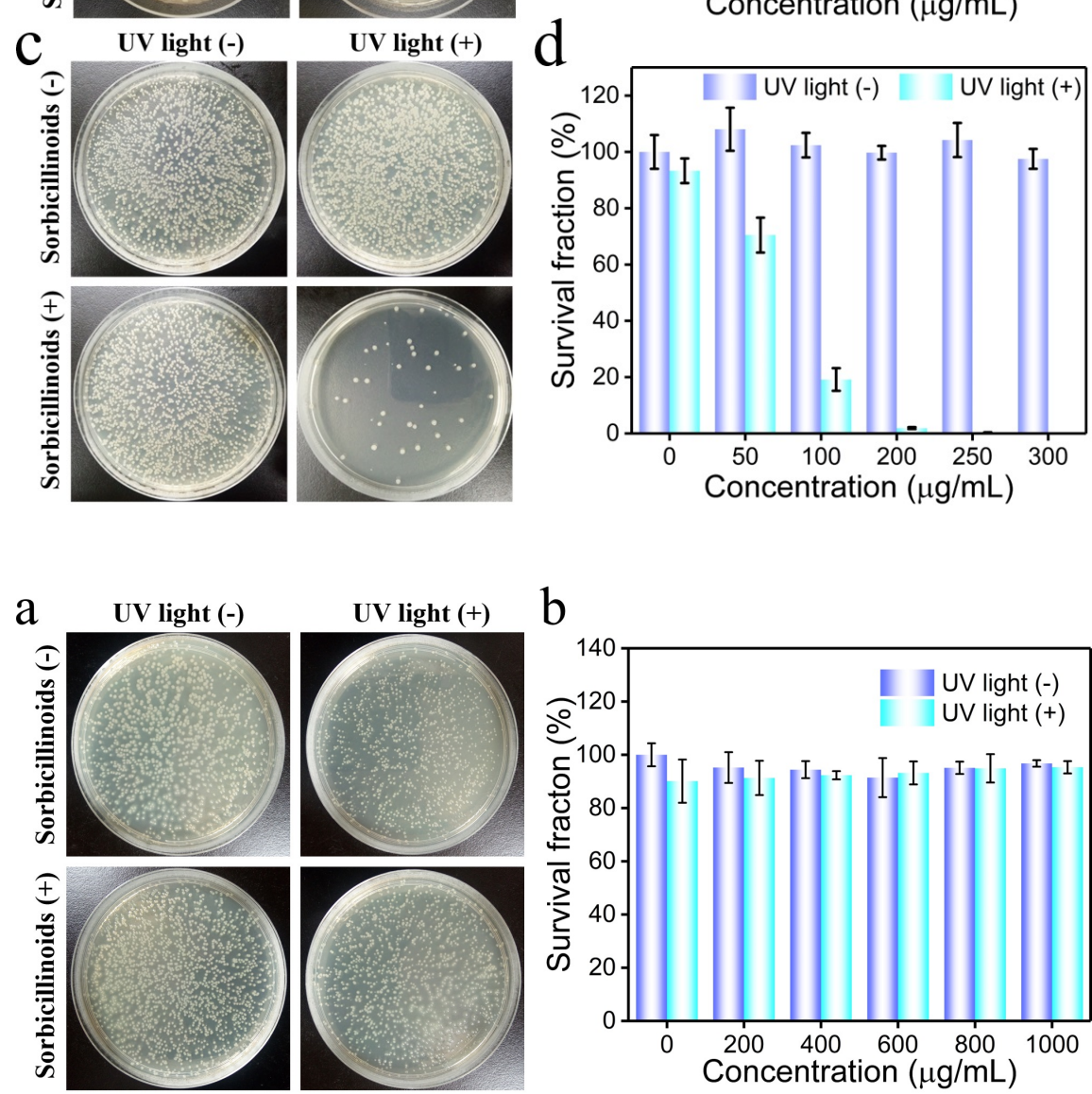

UV light (+) b
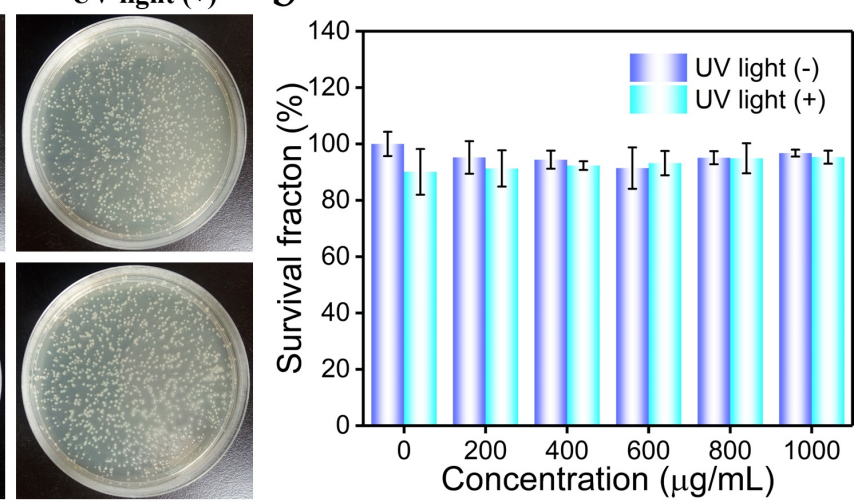

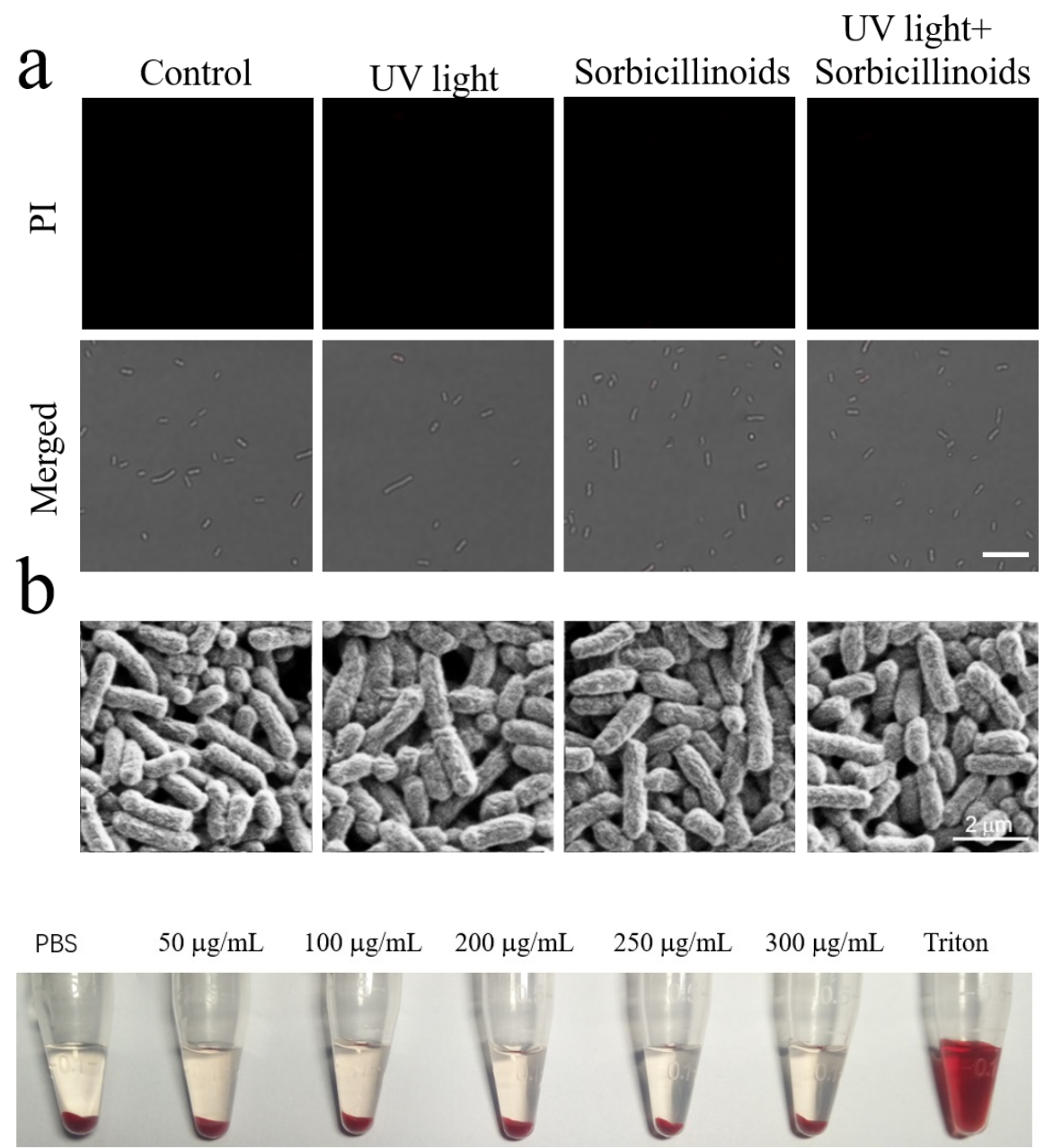